\title{
Participatory, Tourist Consumer Behavior- Based, Integrated Tourism Marketing Plan For Chainat Province
}

\author{
Nak Gulid, Srinakharinwirot University, Thailand \\ Aurathai Lertwannawit, Thammasat Business School, Thammasat University, Thailand
}

\begin{abstract}
This research aims to study Tourist Consumer Behavior, Tourism Market Segmentation, and Tourism Product Positioning in Chainat Province, Thailand. Quantitative analysis is employed in this study. Four hundred Thai tourists who have traveled to Chainat province at least once are the respondents who filled out the questionnaires. Multiple regression analysis has been used in this study. The majority of the Thai tourists are single females between the ages of 25 and 34, employees in the private sector with monthly incomes lower than Baht 10,000 (about USD 300), and are residents in the central region of Thailand. The results show that attitude toward destination, behavioral intention, and destination equity has strong influences on tourist consumer behavior.
\end{abstract}

Keywords: Tourist Consumer Behavior; Behavioral Intention; Attitude toward Destination; Perception on Marketing Communication; Needs/Interest toward Destination; Destination Equity; Chainat Province

\section{INTRODUCTION}

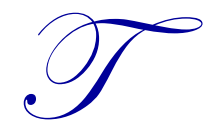

ourism is a major source of income for Thailand and overland travel is the most important transportation method for tourists. Although petroleum prices have increased tremendously, total revenue from foreign tourists has increased from THB367,380 million (USD10,000 million) in 2005 to THB482,319 million (USD14,000 million) in 2006. In contrast, revenue from domestic tourists declined slightly, from THB334,716 million (USD9,900 million) in 2005 to THB322,533 million (USD9,500 Million) in 2006 (www.tat.or.th).

Chainat is one of 76 provinces in Thailand and is located in the central region, 194 kilometers (120 miles) from Bangkok. This province has a long and interesting history, highlighted by a number of temples built in the Ayudhaya era. The area has three main rivers which support abundant agricultural products. The total revenue the province received from domestic tourists increased from THB182 million (USD5.4 million) in 2005 to THB195 million (USD5.7 million) in 2006. Revenue from foreign tourists is only a small proportion of the total when compared to domestic tourists - only THB1 million in 2005, a figure which decreased to THB.88 million in 2006. As indicated above, this work aims to study, through quantitative analysis techniques, tourist consumer behavior, behavioral intention, attitudes toward destination, needs/interest toward destination, destination equity, and perception of marketing communication in Chainat province. Tourism marketing segmentation is also included in this study. Furthermore, qualitative analysis has been employed by using focus-group techniques to study tourism product positioning and by comparing Chainat with 4 neighboring provinces.

\section{Research Interests}

The purpose of this research is to study the impact of independent variables (attitude toward destination, needs/interest toward destination, perception of marketing communication, destination equity, and behavioral intention) on the dependent variable (tourist consumer behavior). 
The following question is addressed in this research:

1. Are there any positive relationships between the independent variables (attitude toward destination, needs/interest toward destination, perception of marketing communication, destination equity, and behavioral intention) and the dependent variable (tourist consumer behavior)?

This study identifies tourism marketing segmentation through quantitative analysis. However, tourism product positioning is found by using qualitative analysis techniques.

\section{LITERATURE REVIEW}

\section{Theory of Planned Behavior}

Ajzen and Fishbein (1991) formulated the theory of reasoned action (TRA) in 1980. This theory states that a person's behavior is determined by his/her intention to perform the behavior. This intention is a function of his/her attitude toward the behavior and his/her subjective norm. The best predictor of behavior is intention. Intention is the cognitive representation of a person's readiness to perform a given behavior and it is considered to be the immediate antecedent of behavior. This intention is determined by three factors: 1) one's attitude toward the specific behavior, 2) one's subjective norms, and 3) one's perceived behavioral control. As a general rule, the more favorable the attitude and the subjective norm, and the greater the perceived control, the stronger should be the person's intention to perform the behavior. The conceptual model is shown in Figure 1.

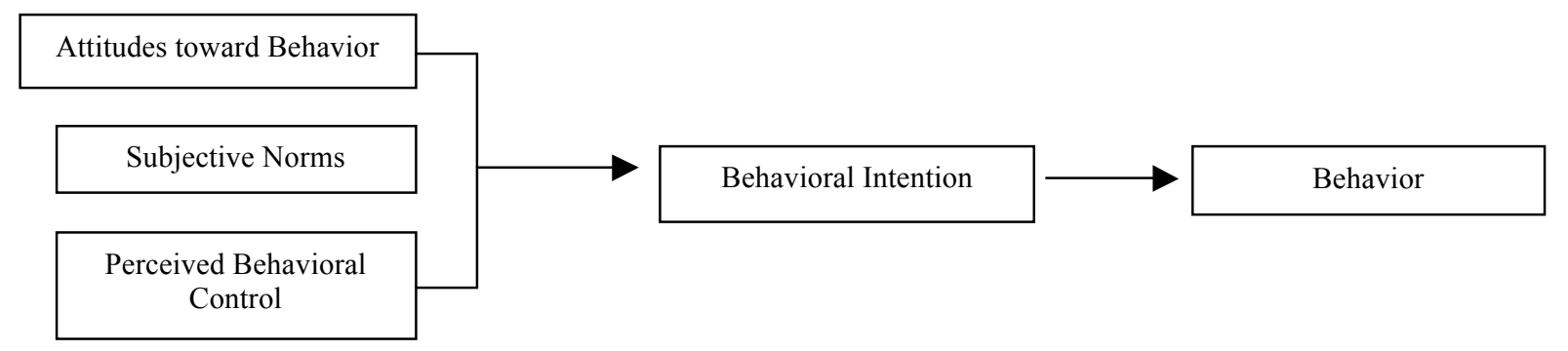

Figure 1: The Theory of Planned Behavior by Ajzen, I. (1991)

According to Ajzen's model, it implies that attitude, perception, needs/interest, and behavior intention have influenced tourist consumer behavior.

\section{Attitude toward Destination}

Traditional models conceive of attitude as having three components - cognitive, affective, and behavioral (Schiffman and Kanuk, 2007). The cognitive dimension involves thoughts or ideas people have about the attitude object, usually referring to beliefs. The affective dimension contains feelings or emotions people experience in regard to the attitude object. The last component - the behavioral dimension of attitude - consists of people's actions with regard to the object (Runyon \& Stewart, 1987). Ajzen and Fishbein (1991) concluded that attitude has influence on intention and behavior. In addition, Baldinger and Rubinson (1996) stated that attitude has affected brand affect and brand loyalty. Attitude toward destination, in this study, includes four dimensions: 1) attitude toward each attraction, 2) attitude toward sustainable tourism, 3) attitude toward history/community/lifestyle, and 4) overall attitude toward destination in Chainat province.

\section{Needs/Interest toward Destination}

Kotler (1999) states that the buyer decision process is composed of five stages: 1) need recognition, 2) information search (personal sources, commercial sources, and public sources), 3) evaluation of alternatives (brand image of self), 4) purchase decision (attitude of other, unexpected situations), and 5) post-purchase behavior (cognitive dissonance). Each stage of each tourist typology will be different (Krippendorf, 1987). For example, 
backpackers may need a different level of recognition and different method of information search compared to mass tourists.

Consumers adjust purchasing behavior based on their individual needs and interpersonal factors. In order to understand these influences, researchers try to ascertain what happens inside consumers' minds and to identify physical and social exterior influences on purchase decisions. It is necessary to understand what compels the consumer to actually make a purchase, as opposed to just generating interest. For example, some consumers respond based on how they are feeling - or more emotionally - while others are focused on making the wisest economic decision (Hawkins et al. 2003).

\section{Perception of Marketing Communication}

"Among the several factors that impact destination image, the influential role of information provided by the visual media, such as movies, has been empirically supported not only on destination-image formation, but also on subsequent consumer behavior (Tooke and Baker 1996; Hanefors and Mossberg 2002; Morgan, Prichard, and Piggott 2003; Riley, Baker, and Doren 1998). Positive reflections in the visual media might help reduce the perceived cultural and social differences and distances, stereotypes, and biases in image. Prejudices and stereotypes are more likely to exist in lack of familiarity, dictating perceptions about - and the level of social distance felt toward - "others" (Bochner, 1982). In lack of familiarity, prejudices and stereotypes can be instrumental in increasing social distance, distorting destination-image and reducing the likelihood of subsequent tourist behavior such as visitation, satisfaction, and recommendation. Generally, two categories of information are commonly identified - the promotional materials from the destination and various types of independent media (Gartner, 1993; Gunn, 1972). Information from both of these sources can have verbal, visual, audio - or combination of - messages. Using various promotional tools, including visuals, destination marketers try to project desirable images to attract tourists. Tourist places gain symbolic meanings produced by place producers (destination promoters) and by place consumers (visitors). Hence, this study included both of these meanings," (Tasci, 2008).

\section{Destination Equity}

Several studies attempted to link customer-based brand equity constructs with the Hierarchy of Effects (HOE) model, an advertising effectiveness tool introduced by Robert Lavidge (1961) and used as a tool to evaluate advertising effectiveness. The model consists of three components: cognitive, affective, and conative (behavioral). It assumes that potential buyers are new users who move from awareness to knowledge to linking to preference to intention to buy to actual purchase over time. In addition, several empirical studies in the literature supported the positive relationship between customer-based brand equity constructs and brand preference and purchase intention (Cobb-Walgren et al., 1995; Agarwal \& Rao, 1996; Vakratsas \& Ambler, 1999; Mackay, 2001b; Myers, 2003). These relationships are shown in Figure 2.

\begin{tabular}{|l|l|}
\hline Customer-Based Brand Equity & Brand Preference \\
\cline { 2 - 2 }
\end{tabular}

Figure 2: Customer-Based Brand Equity with the Hierarchy of Effects (HOE) Model

Agawal \& Rao (1996) developed a model that links brand equity to the Hierarchy of Effects model. They focused on single composite measures of brand equity, assessing the impact of individual measures on market share (Mackay, 2001b). Mackay (2001b) employed Agawal \& Rao’s model (1996) on the service industry.

\section{Behavioral Intention}

Behavioral intentions include desirable behaviors that visitors anticipate they will exhibit in the future. Zeithaml et al. (1996) developed a 13-item battery to measure a wider range of behavioral intentions. The battery included items such as likelihood of paying a price premium and remaining loyal to a company even when its prices go up, intent to do more business with the firm in the future, and complaint intentions when service problems occur. All 13 items can be grouped into five dimensions: 1) loyalty to company, 2) propensity to switch, 3) willingness to pay more, 4) external response to a problem, and 5) internal response to a problem. Among these five dimensions, 
loyalty and willingness to pay more receive the highest factor scores. Loyalty is defined as a biased behavior expressed over time by a visitor with respect to one or more alternatives and is a function of psychological processes (Jacoby and Kyner, 1973). It has been argued to be a two-dimensional construct measured by both behavior and attitude (Baker and Crompton, 2000). This study adopted Zeithaml et al. (1996) methods to measure behavioral intentions and specified only on loyalty dimension.

\section{Tourist Consumer Behavior}

McColl et al. (1994, p. 116) define consumer behavior as 'the actions a person takes towards purchasing and using products and services, including the decision-making process that precedes and determines the actions'. From this statement, it is possible to say that actions carried out by tourists are very important for development of the tourism industry. Poon (1994) concludes that tourists are the products of changing population demographics and are more experienced, flexible, and independent-minded. Tourists have changed values and lifestyles which affect tourist demand. Asian people are now looking for value-added holidays and prefer an urban experience, while American tourists look for cultural and educational values (Swarbrooke and Horner, 1999). Kotler (1999) states that globalization has changed tourist consumer behavior as it has the capacity to create impacts on 1) cultural criteria (culture, subculture, social class), 2) social criteria (reference groups, family, roles, and status), 3) personal criteria (age and life cycle stage, occupation, economic circumstances, lifestyle, personality and self-concept), and 4) psychological criteria (motivation, perception, learning, beliefs, and attitudes). Ajzen and Fishbein (1991) stated that a person's behavior is determined by his/her intention to perform the behavior. This intention is a function of his/her attitude toward the behavior and his/her subjective norm. The best predictor of behavior is intention. Intention is the cognitive representation of a of a person's readiness to perform a given behavior and it is considered to be the immediate antecedent of behavior. According to the above statement, attitudes toward tourism, behavioral intention, perception on marketing communication, and destination equity are the important factors driving tourist consumer behavior. The conceptual framework based on Kotler (1999) and Ajzen (1991) is shown in Figure 3.

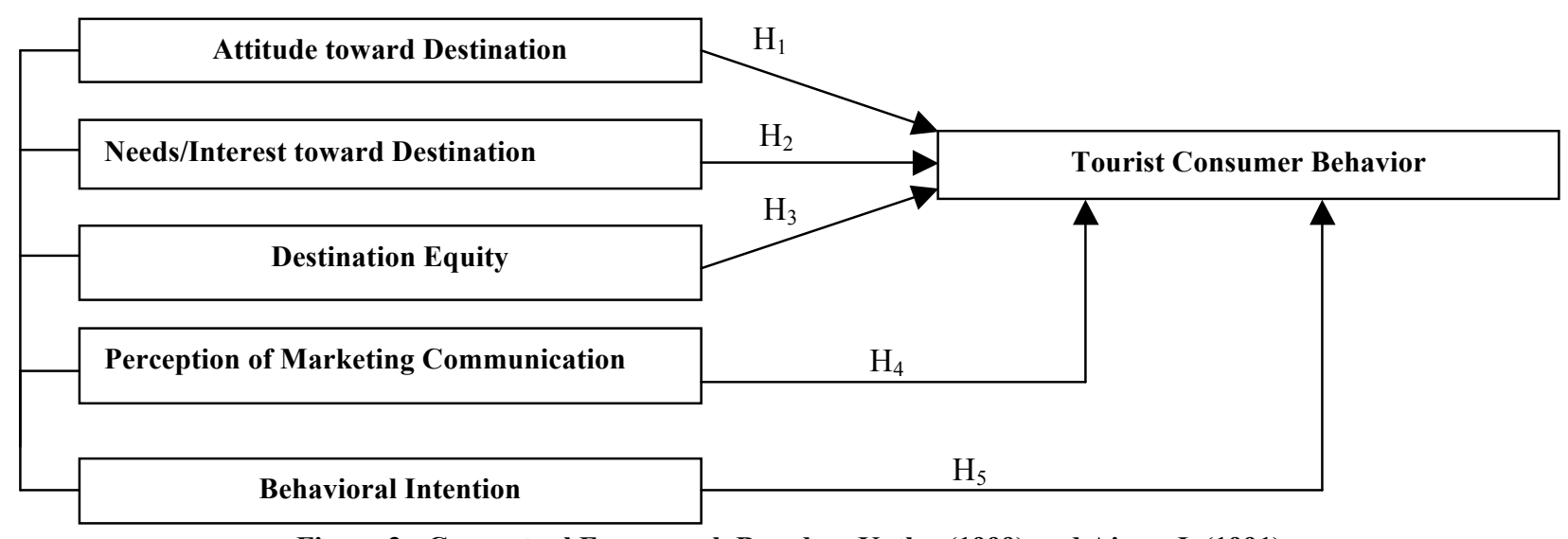

Figure 3: Conceptual Framework Based on Kotler (1999) and Ajzen, I. (1991)

\section{Hypotheses}

This section provides the set of hypotheses for testing the determination of tourist consumer behavior:

$\mathbf{H}_{1}$ : There is a positive relationship between attitude toward destination and tourist consumer behavior.

$\mathbf{H}_{2}$ : There is a positive relationship between needs/interest toward destination and tourist consumer behavior.

$\mathbf{H}_{3}$ : $\quad$ There is a positive relationship between destination equity and tourist consumer behavior.

$\mathbf{H}_{4}$ : There is a positive relationship between perception of marketing communication and tourist consumer behavior.

H5: There is a positive relationship between behavioral intention and tourist consumer behavior. 


\section{RESEARCH METHODOLOGY}

This study employs qualitative and quantitative analyses. Concerning quantitative analysis, the total population is domestic tourists who traveled to Chainat province at least one time. This study does not include international tourists because the number of international tourists is less than one percent of total tourists (984 of 242,131 , www.tat.or.th). The total sample size is 400 domestic tourists. The sampling method is purposive in five attractions in Chainat province, including the bird park, Chao Phraya dam, the harbor, Wat Pak Klong tamarind, and Thammamun Worawihan temple. Quota sampling was employed for each attraction; therefore, 80 tourists were interviewed at each site. Convenience sampling was applied in selecting the sample size of each attraction.

Concerning qualitative analysis, 30 stakeholders were selected from entrepreneurs, government officers, community leaders, and tourists. The focus-group technique was employed in this study. The unstructured interview was also applied in this analysis.

\section{Measures}

All measurement items of each construct and its Cronbach alpha level are summarized in Table 1. All measures achieved Cronbach alpha level beyond the recommend level of 0.60 passing the minimum requirement.

Table 1: Reliability of Measures Used in the Current Study

\begin{tabular}{|l|c|}
\hline \multicolumn{1}{|c|}{ Scales Items } & Cronbach's Alpha \\
\hline Attitude toward Destination, 4 Dimensions with 43-Item Scale on a Five-Point Rating Scale & .932 \\
\hline - attitude toward each destination & .733 \\
\hline - attitude toward sustainable tourism & .897 \\
\hline - attitude toward history/community/lifestyle & .895 \\
\hline - overall attitude toward destination in Chainat province & .935 \\
\hline Needs/Interest toward Destination, 13-Item Scale on a Five-Point Rating Scale & .806 \\
\hline Perception of Marketing Communication, 5-Item Scale with Five-Point Rating Scale & .880 \\
\hline Destination Equity, 3 Dimensions with 18-Item Scale on a Five-Point Likert Rating Scale & .936 \\
\hline - awareness & .922 \\
\hline - value for money & .907 \\
\hline - overall quality of attractions & .886 \\
\hline Behavioral Intention, 4-Item Scale on a Five-Point Sementic Differential Scale & \\
\hline Tourist Consumer Behavior, 6-Item Scale on a Five-Point Rating Scale & \\
\hline
\end{tabular}

\section{FINDINGS/DISCUSSIONS}

\section{Respondent Profile}

Four hundred domestic tourists were interviewed for quantitative analysis. The result of all respondents showed that the majority of tourists were female $(61.2 \%)$ and $47 \%$ were between 25 and 34 years old. They were single $(52.3 \%)$ and had bachelor degrees $(61.2 \%)$. A number of them were employed in private companies $(37.5 \%)$ and $31.5 \%$ earned monthly income that was lower than THB10,000 (about USD300). Many came from the central region (35.8\%), followed by Bangkok (32.3\%), and the western region (12.5\%). All details are included in Table 2: 
Table 2: Respondent Profile of Tourists

\begin{tabular}{|c|c|c|}
\hline Demographic Profile & Frequency & Percent \\
\hline \multicolumn{3}{|l|}{ Gender } \\
\hline Male & 155 & 38.8 \\
\hline Female & 245 & 61.2 \\
\hline Total & 400 & 100.0 \\
\hline \multicolumn{3}{|l|}{ Age } \\
\hline Under 15 years & 6 & 1.5 \\
\hline $15-24$ years & 70 & 17.5 \\
\hline $25-34$ years & 188 & 47.0 \\
\hline $35-44$ years & 55 & 13.8 \\
\hline $45-54$ years & 61 & 15.2 \\
\hline 55-64 years & 15 & 3.8 \\
\hline 65 years and over & 5 & 1.2 \\
\hline Total & 400 & 100.0 \\
\hline \multicolumn{3}{|l|}{ Marital Status } \\
\hline Single & 209 & 52.3 \\
\hline Married/Living Together & 177 & 44.2 \\
\hline Divorced/Separated/Widowed & 14 & 3.5 \\
\hline Total & 400 & 100.0 \\
\hline \multicolumn{3}{|l|}{ Education Level } \\
\hline Lower than Bachelor Degree & 119 & 29.8 \\
\hline Bachelor Degree & 245 & 61.2 \\
\hline Higher than Bachelor Degree & 36 & 9.0 \\
\hline Total & 400 & 100.0 \\
\hline \multicolumn{3}{|l|}{ Occupation } \\
\hline Employed in a private company & 150 & 37.5 \\
\hline Government/ State enterprise & 126 & 31.5 \\
\hline Entrepreneurs & 22 & 5.5 \\
\hline Students & 51 & 12.8 \\
\hline Retired/unemployed & 9 & 2.3 \\
\hline Housewives & 9 & 2.3 \\
\hline Professionals & 7 & 1.8 \\
\hline Administrative/Management & 2 & 0.5 \\
\hline Farmers & 8 & 2.0 \\
\hline Laborers & 13 & 3.3 \\
\hline Other, Please specify (such as two occupations) & 3 & 0.8 \\
\hline Total & 400 & 100.0 \\
\hline \multicolumn{3}{|l|}{ Monthly Income } \\
\hline Lower than USD300 & 126 & 31.5 \\
\hline USD $300-450$ & 106 & 26.5 \\
\hline USD450-600. & 74 & 18.5 \\
\hline USD600-750 & 28 & 7.0 \\
\hline USD750 and over & 66 & 16.5 \\
\hline Total & 400 & 100.0 \\
\hline \multicolumn{3}{|l|}{ Residence } \\
\hline Bangkok & 130 & 32.4 \\
\hline Central region, such as Chainat (60 persons) & 143 & 35.8 \\
\hline Northern region, such as Nakhon Sawan (14 persons) & 38 & 9.5 \\
\hline Southern region, such as Nakhon Srithammarat (4 persons) & 10 & 2.5 \\
\hline Northeastern region, such as Nakhon Ratchasrima (5 person) & 20 & 5.0 \\
\hline Eastern region, such as Nakhonnayok (4 persons) & 9 & 2.3 \\
\hline Western region, such as Ratchaburi (47 persons) & 50 & 12.5 \\
\hline Total & 400 & 100.0 \\
\hline
\end{tabular}




\section{RESULTS}

Multiple regression analysis is employed for the quantitative analysis. The result indicates that attitudes toward destination, destination equity, and behavioral intention have a strong impact on tourist consumer behavior, which supports $\mathrm{H}_{1}, \mathrm{H}_{2}$, and $\mathrm{H}_{3}$. The equation is:

Tourist consumer behavior $=.277^{* *}$ behavioral intention $+.149^{* *}$ attitude toward destination $+.113^{* *}$ destination equity

Adjusted $R^{2}=.319^{* *}$ indicates statistical significance at .01 level.

Furthermore, this study employs two-step cluster analysis by using rational motivation, emotional motivation, and destination equity of all three dimension factors to determine the targeted group and the subordinate group for travel to Chainat province. The result divides tourists into three groups. The first group is called Chainat lovers (130 tourists) due to the highest mean score compared to other groups. The second group is called Chainat pending (210 tourists) and it received the lowest mean score. The last group is called Chainat fond (60 tourists) of which the mean score is on a moderate level compared to the other groups. The results are indicated in Table 3:

Table 3: Targeted Market Using Two-Step Cluster Analysis

\begin{tabular}{|l|c|c|c|c|c|c|c|c|}
\hline \multirow{2}{*}{ Dependent Variables } & \multicolumn{2}{|c|}{$\begin{array}{c}\text { First Group } \\
(\mathbf{n = 1 3 0}\end{array}$} & \multicolumn{2}{c|}{$\begin{array}{c}\text { Second Group } \\
(\mathbf{n = 2 1 0})\end{array}$} & \multicolumn{2}{c|}{$\begin{array}{c}\text { Third Group } \\
(\mathbf{n}=\mathbf{6 0})\end{array}$} & \multicolumn{2}{c|}{$\begin{array}{c}\text { Total } \\
(\mathbf{n}=\mathbf{4 0 0})\end{array}$} \\
\cline { 2 - 10 } & Mean & S.D. & Mean & S.D. & Mean & S.D. & Mean & S.D. \\
\hline Rational Motivation & $\mathbf{3 . 7 7}$ & .781 & 3.36 & .741 & 3.60 & .918 & 3.53 & .803 \\
\hline Emotional Motivation & $\mathbf{3 . 5 6}$ & .740 & 3.18 & .675 & 3.55 & .778 & 3.36 & .736 \\
\hline Destination Equity: awareness & $\mathbf{3 . 5 0}$ & .691 & 2.89 & .689 & 3.25 & .797 & 3.14 & .757 \\
\hline Destination Equity: value for money & $\mathbf{3 . 2 5}$ & .615 & 2.89 & .586 & 3.19 & .734 & 3.05 & .641 \\
\hline Destination Equity: overall quality of attractions & 3.44 & .720 & 3.05 & .703 & $\mathbf{3 . 4 5}$ & .777 & 3.24 & .746 \\
\hline
\end{tabular}

Additionally, one-way analysis of variance is employed to compare the difference between the three groups. The results are shown in Table 4.

Table 4: Results of ANOVA Comparing the Three Groups on Five Factors

\begin{tabular}{|c|c|c|c|c|c|c|c|c|}
\hline \multicolumn{2}{|c|}{ Dependent Variables } & $\begin{array}{c}\text { Levene } \\
\text { Test }\end{array}$ & Sig. & $\begin{array}{c}\text { Sum of } \\
\text { Squares }\end{array}$ & df & $\begin{array}{c}\text { Mean } \\
\text { Square } \\
\end{array}$ & $\mathbf{F}$ & $\mathbf{p}$ \\
\hline \multirow{4}{*}{$\begin{array}{l}\text { Rational } \\
\text { Motivation }\end{array}$} & Between groups & 2.847 & .059 & 13.959 & 2 & 6.979 & $11.398 * *$ & .000 \\
\hline & Within groups & & & 243.107 & 397 & .612 & & \\
\hline & Total & & & 257.066 & 399 & & & \\
\hline & & $\begin{array}{c}\text { Levene } \\
\text { Test }\end{array}$ & Sig. & df1 & df2 & \multicolumn{2}{|c|}{ Brown-Forsythe } & $\mathbf{p}$ \\
\hline $\begin{array}{l}\text { Emotional } \\
\text { Motivation }\end{array}$ & & $4.612 *$ & .010 & 2 & 209.838 & \multicolumn{2}{|c|}{$13.080 * *$} & .000 \\
\hline & & $\begin{array}{c}\text { Levene } \\
\text { Test }\end{array}$ & Sig & $\begin{array}{c}\text { Sum of } \\
\text { Squares }\end{array}$ & df & $\begin{array}{c}\text { Mean } \\
\text { Square } \\
\end{array}$ & $\mathbf{F}$ & $\mathbf{p}$ \\
\hline \multirow{3}{*}{$\begin{array}{l}\text { Destination } \\
\text { equity: awareness }\end{array}$} & Between groups & 2.063 & .128 & 30.242 & 2 & 15.121 & $30.255^{* *}$ & .000 \\
\hline & Within groups & & & 198.414 & 397 & .500 & & \\
\hline & Total & & & 228.655 & 399 & & & \\
\hline \multirow{3}{*}{$\begin{array}{l}\text { Destination } \\
\text { equity: value for } \\
\text { groups money }\end{array}$} & Between groups & 2.762 & .064 & 11.445 & 2 & 5.722 & $14.919 * *$ & .000 \\
\hline & Within groups & & & 152.274 & 397 & .384 & & \\
\hline & Total & & & 163.719 & 399 & & & \\
\hline \multirow{3}{*}{$\begin{array}{l}\text { Destination } \\
\text { equity: overall } \\
\text { quality of } \\
\text { attractions }\end{array}$} & Between groups & 2.161 & .117 & 15.920 & 2 & 7.960 & $15.351 * *$ & .000 \\
\hline & Within groups & & & 205.865 & 397 & .519 & & \\
\hline & Total & & & 221.785 & 399 & & & \\
\hline
\end{tabular}

** Statistical significance of 0.01 levels

Based on Table 4, the results indicate that different groups of tourists affect motivation and equity at statistical significance of 0.01 levels. Table 5 shows the LSD test comparing the three different groups of tourists. 
Table 5: Results of LSD Test-Multiple Comparisons of the Three Groups on Five Factors

\begin{tabular}{|c|c|c|c|c|c|c|}
\hline \multicolumn{4}{|c|}{ Dependent Variables } & \multirow{2}{*}{$\begin{array}{c}\text { Mean } \\
\text { Differences } \\
\text { On First } \\
\text { Group } \\
- \\
\end{array}$} & \multirow{2}{*}{$\begin{array}{c}\text { Mean } \\
\text { Differences } \\
\text { On Second } \\
\text { Group } \\
0.41^{* *}\end{array}$} & \multirow{2}{*}{$\begin{array}{c}\text { Mean } \\
\text { Differences } \\
\text { On Third } \\
\text { Group } \\
0.17 \\
\end{array}$} \\
\hline \multirow{3}{*}{$\begin{array}{l}\text { Rational Motivation } \\
\text { (LSD) }\end{array}$} & First group & Mean $=$ & 3.77 & & & \\
\hline & Second group & Mean $=$ & 3.36 & - & - & $-0.24 * *$ \\
\hline & Third group & Mean $=$ & 3.60 & - & - & - \\
\hline \multirow{3}{*}{$\begin{array}{l}\text { Emotional Motivation } \\
\text { (Dunnett T3) }\end{array}$} & First group & Mean $=$ & 3.56 & - & $0.38 * *$ & -0.01 \\
\hline & Second group & Mean $=$ & 3.18 & - & - & $-0.37 * *$ \\
\hline & Third group & Mean $=$ & 3.55 & - & - & - \\
\hline \multirow{3}{*}{$\begin{array}{l}\text { Destination Equity: awareness } \\
\text { (LSD) }\end{array}$} & First group & Mean $=$ & 3.50 & - & $0.61 * *$ & $0.25^{*}$ \\
\hline & Second group & Mean $=$ & 2.89 & - & - & $-0.36^{* *}$ \\
\hline & Third group & Mean $=$ & 3.25 & - & - & - \\
\hline \multirow{3}{*}{$\begin{array}{l}\text { Destination Equity: value for } \\
\text { money (LSD) }\end{array}$} & First group & Mean $=$ & 3.25 & - & $0.36^{* *}$ & 0.06 \\
\hline & Second group & Mean $=$ & 2.89 & - & - & $-0.30 * *$ \\
\hline & Third group & Mean $=$ & 3.19 & - & - & - \\
\hline \multirow{3}{*}{$\begin{array}{l}\text { Destination Equity: overall quality } \\
\text { of attractions (LSD) }\end{array}$} & First group & Mean $=$ & 3.44 & - & $0.39 * *$ & -0.01 \\
\hline & Second group & Mean $=$ & 3.05 & - & - & $-0.40 * *$ \\
\hline & Third group & Mean $=$ & 3.45 & - & - & - \\
\hline
\end{tabular}

* Statistical significance of 0.05 levels. ** Statistical significance of 0.01 levels

Based on Table 5, the results show that tourism market segmentation can be divided into two groups: 1) Chainat lover and 2) Chainat pending. The Chainat lover group includes the first and third groups because the mean score is quite high in both groups. Additionally, the mean differences of both groups are inconsequential at any statistical significance level, except on the awareness dimension. The result shows that the mean scores between the Chainat lover group and the Chainat pending group (first and second groups in the table) are different at a statistical significance of 0.01 levels for all variables.

\section{CONCLUSIONS}

It can be concluded that tourist consumer behavior is mainly driven by behavioral intention, attitude toward destination, and destination equity, in that order. Concerning the tourism categories, religious tourism and manmade attractions are the strongest categories of Chainat province when compared to four neighboring provinces. In contrast, Chainat should put more emphasis on integrated marketing communication. The reason is that tourists, and even local residents, do not have enough information about the many beautiful attractions to be found in Chainat. Additionally, Chainat should renovate its famous attractions, such as the bird park and Thammamun Worawihan temple, to attract more tourists.

\section{LIMITATIONS AND FURTHER RESEARCH}

First, the ability to generalize the findings is limited since this study was conducted at one destination only. Second, based on the value of Adjusted $\mathrm{R}^{2}(32 \%)$ - the percentage of variance accounted for by tourist consumer behavior in Chainat province - future research can investigate the effects of factors such as value, brand personality, and so on (Gulid, etc., 2009). Third, according to the profile of domestic tourists, future studies should target foreign tourists. Finally, to gain more information on tourist consumer behavior, it is more appropriate to study the same sample and same variables over time.

\section{AUTHOR INFORMATION}

Nak Gulid received his Ph.D. in Economics, International Trade and Finance as major areas from University of Missouri-Columbia, U.S.A. in 1994 and his Ph.D. in Marketing from Thammasat University in 2007, Thailand. His interested field area includes International Business, Marketing, Hospitality and Tourism, and Management. He is now the Director of MBA program at Srinakharinwirot University. E-mail: nakgulid@gmail.com (Corresponding author) 
Assistant Professor Aurathai Lertwannawit received her Ph.D. in Marketing from Thammasat University in 2006. The interested research areas include Marketing, Hospitality and Tourism. She is a full-time lecturer in the Marketing Department, Thammasat Buinsess School, Thammasat University, Thailand. E-mail: aurathai@tbs.tu.ac.th

\section{REFERENCES}

1. Agarwal, M.K. and V.R. Rao (1996). An Empirical Comparison of Consumer-Based Measures of Brand Equity. Marketing Letters, 7, 3: 237-47.

2. Ajzen, I. and M. Fishbein. (1991). The Theory of Planned Behavior. Organizational Behavior and Human Decision Processes, 50(2), 179-21.

3. Baker, D.A. and J.L. Crompton. (2000). Quality, Satisfaction, and Behavioral Intentions. Annals of Tourism Research, 27(3), 785-804.

4. Balinger, Allan L., and Joel Rubinson. (1996). Brand Loyalty: The Link between Attitude and Behavior. Journal of Advertising Research, 36(6), 22-34.

5. Bochner, S. (1982). The Social Psychology of Cross-Cultural Relations, in Cultures in Contact-Studies in Cross-Cultural Interaction, edited by S. Bochner. New York: Pergamon, 5-44.

6. Cobb-Walgren, Cathy, J., Cynthia A. Ruble, and Naveen Donthu. (1995). Brand Equity, Brand Preference, and Purchase Intent. Journal of advertising, 24, 3 (Fall): 25-40.

7. Gartner, W.C. (1989). Image Formation Process. Journal of Travel and Tourism Research, 2(2): 191-215.

8. Gulid, Nak, Sirivan, S., Suphada, S., Udom, S., Aurathai L., Nongluck, P. (2009).Thai Silk Product Industry Development in Northeastern Region. International Business and Economics Research Journal 8, 10 (October), 35-42.

9. Gunn, C. (1972). Vacationscape: Designing Tourist Regions. Austin: Bureau of Business Research, University of Texas.

10. Hanefors, M., and L. Mossberg. (2002). TV Travel Shows-A Pre-taste of the Destination. Journal of Vacation Marketing, 8(3): 235-46.

11. Hawkins, Delbert, Best, Roger, Coney, Kenneth. (2003). Consumer Behavior: Building Marketing Strategy. $9^{\text {th }}$ ed. New York: McGraw-Hill, USA.

12. Jacoby, J., and D. Kyner. (1973). Brand Loyalty versus Repeat Purchasing Behavior. Journal of Marketing Research, 10: 1-9.

13. Kotler, P., Bowen, J. and Makens, J. (1999). Marketing for Hospitality and Tourism. $2^{\text {nd }}$ ed., Prentice Hall, USA.

14. Krippendorf, J. (1987). The Holidaymakers: Understanding the Impacts of Leisure and Travel, Heinemann, London.

15. Lavidge, Robert J. (1961). A Model for Predictive Measurements of Advertising Effectiveness. Journal of Marketing, 25, 6 (October): 59-62.

16. Mackay, Marisa Maio (2001b). Application of Brand Equity Measures in Service Markets. The Journal of Services Marketing, 15, 3: 210-21.

17. McColl, K. Jr., Kiel, G.G., Lusch, R.F., and Lusch, V.N. (1994). Marketing: Concepts and Strategies. Acumen Overseas Pte. Ltd, Singapore.

18. Morgan, N.J., A. Pritchard, and r. Piggott. (2003). Destination Branding and the Role of the Stakeholders: The Case of New Zealand. Journal of Vacation Marketing, 9(3): 285-97.

19. Myers, Chris A. (2003). Managing Brand Equity: A Look at the Impact of Attributes. The Journal of Product and Brand Management, 12, 1: 39-51.

20. Poon, A. (1994). Tourism, Technology and Competitive Strategies, Cab Interantional.

21. Riley, R., D. Baker, and C.S. V. Doren. (1998). Movie Induced Tourism. Annals of Tourism Research, 25(4): 919-35.

22. Runyon, K.E., \& Stewart, D.W. (1987). Consumer Behavior and the Practice of Marketing. $3^{\text {rd }}$ ed. Columbus, Ohio: Merrill, USA.

23. Schiffman, Leon G.; Kanuk, Leslie Lazer. (2007). Consumer Behavior. $9^{\text {th }}$ ed. New Jersey: Prentice-Hall, USA.

24. Swarbrooke, J., and Horner, S. (1999). Consumer Behavior in Tourism. Butterworth-Heiemann, Great Britain. 
25. Tooke, N., and M. Baker. (1996). Seeing in Believing: The Effect of Film on Visitor Numbers to Screened Locations. Tourism Management, 17(2): 87-94.

26. Tasci, A.D.A (2008). Social distance: the missing link in the loop of movies, destination imabe, and tourist behavior? Journal of Travel Research. 47: 494-507.

27. Vakratsas, Dermetrios and Tim Ambler. (1999). How Advertising Works: What Do We Really Know? Journal of Marketing, 63, 1 (January), 9: 97-104.

28. Zeithaml, V.A., L. L. Berry, and A. Parasuraman (1996). The Behavioral Consequences of Service Quality. Journal of Marketing, 60(April): 31-46.

29. www.tat.or.th 